\title{
PENGEMBANGAN KOMIK MANGA BIOLOGI BERBASIS ANDROID UNTUK PESERTA DIDIK KELAS XI DITINGKAT SMA/MA
}

\author{
Nukhbatul Bidayati Haka ${ }^{(1)}$, Suhanda ${ }^{(2)}$ \\ ${ }^{(1)}$ Dosen Program Studi Pendidikan Biologi Universitas Islam Negeri Raden Intan \\ Lampung (contact person 0857-6830-9887 / email : \\ Nukhbatul.Bidayati7@gmail.com) \\ (2) Mahasiswa Pendidikan Biologi Universitas Islam Negeri Raden Intan Lampung \\ (contact person 082377686412 / email : suhanda44.44@gmail.com)
}

\begin{abstract}
ABSTRAK
Pada pembelajaran biologi sarana dan prasarana penunjang pembelajaran serta perkembangan teknologi seperti android milik peserta didik belum dijadikan media pembelajaran. Alternatifnya dengan mengembangkan media pembelajaran komik manga digital berbasis android untuk memudahkan pemahaman materi biologi. Penelitian ini bertujuan untuk: 1.) Mengetahui cara pengembangan media pembelajaran komik manga digital berbasis android pada materi sistem hormon untuk kelas XI di MAN 2 Bandar Lampung yang memudahkan materi belajar biologi oleh peserta didik. 2.) Mengetahui kelayakan pengembangan media komik manga digital berbasis android pada materi sistem hormon untuk peserta didik kelas XI berdasarkan penilaian ahli materi, ahli bahasa, ahli media, guru biologi, dan peserta didik. Penelitian ini merupakan Research and Development (R\&D), tahapan yang digunakan yaitu hanya sampai pada tahap ketujuh dari sepuluh tahapan. Penelitian ini dilakukan di MAN 2 Bandar Lampung pada peserta didik kelas XI MIA 1. Penilaian ahli materi sangat layak berpersentase $83,75 \%$, penilaian ahli bahasa sangat layak berpersentase $93,75 \%$, penilaian ahli media sangat layak berpersentase $85,8 \%$. Sedangkan pada repson guru berpersentase $86,25 \%$, dan respon peserta didik kelas XI berpersentase 82,4\% di MAN 2 Bandar Lampung. Berdasarkan penilaian tersebut kualitas media pembelajaran komik manga digital pada materi sistem hormon dinyatakan dalam kriteria sangat layak digunakan sebagai media pembelajaran.
\end{abstract}

Kata kunci : Android, Komik Manga Biologi 


\begin{abstract}
In learning biology facilities and infrastructure supporting learning and technological developments such as android owned by learners have not been used as a medium of learning. The alternative is to develop android-based digital manga comic learning media to facilitate the understanding of biological materials. This study aims to: 1.) Knowing how to develop android-based digital manga comic learning media on hormonal system material for class XI in MAN 2 Bandar Lampung that facilitate biology learning materials by learners. 2.) To determine the feasibility of developing comic-based digital manga media based on the hormonal system material for students of class XI based on the assessment of material experts, linguists, media experts, biology teachers, and learners. This research represents Research and Development $(R \& D)$, it research stages used are only up to the seventh stage of the ten stages. This research was conducted at MAN 2 BandarLampung on students of class XI MIA 1. Assessment of material experts is very decent percentage $83.75 \%$, the assessment of linguists is very decent berpententase $93.75 \%$, assessment of media experts is very decent percentage $85.8 \%$. While the repson teachers berpersentase $86.25 \%$, and the response class XI students berpersentase $82.4 \%$ in MAN 2 Bandarlampung. Based on the assessment of the quality of learning media of digital manga comic on hormonal system material expressed in criteria is very suitable to be used as a medium of learning.
\end{abstract}

\title{
Keywords: Android; Comics Manga Biology
}

\section{PENDAHULUAN}

Ilmu pengetahuan alam merupakan satu dari berbagai pembelajaran yang berkaitan dengan kehidupan sehari-hari peserta didik, Ilmu Pengetahuan Alam juga diperlukan untuk memenuhi kebutuhan manusia melalui pemecahan masalah- masalah yang diidentifikasikan (Sudarma, Murda, Rediarta, 2014:2). IPA merupakan salah satu cabang keilmuan antara ilmu biologi, ilmu fisika, ilmu kimia.

Berdasarkan cabang keilmuan tersebut, cabang Ilmu Pengetahuan Alam yang harus dikuasai peserta didik adalah ilmu biologi. Mata pelajaran biologi merupakan salah satu bidang IPA yang dibangun atas dasar produk ilmiah, proses ilmiah, dan sikap ilmiah (Sudarma, Murda, Rediarta, 2014:2). Selama pembelajaran biologi peserta didik dituntut untuk aktif dalam mengemukakan konsep-konsep utama dari materi biologi baik melalui kegiatan observasi, kegiatan eksperimen, media gambar, media grafik, media tabel, dan mengkomunikasikan hasilnya pada orang lain. Biologi sebagai ilmu yang 
mempelajari tentang makhluk hidup, umumnya menggunakan istilah atau bahasa latin untuk memahami sebuah materi. Proses pembelajaran biologi akan lebih bermakna apabila sesuai dengan tujuan pembelajaran. Dengan begitu peserta didik merasa senang atau mudah mendalami materi yang disampaikan dalam pembelajaran biologi.

Tujuan pembelajaran dapat tercapai dan proses belajar-mengajar yang tidak membosankan akan tercipta, jika guru memahami secara tepat tentang tingkat perkembangan anak. Dengan pemahaman tersebut guru diharapkan dapat menempatkan lahan baca yang menarik untuk menumbuhkan motivasi peserta didik untuk belajar. Dengan penggunaan media, peserta didik akan merasa senang atau mudah mendalami materi dan terciptanya pembelajaran yang lebih bermakna. Media merupakan salah satu sarana untuk mempermudah penyampaian materi dari guru kepada peserta didik, dengan adanya media atau alat-alat penunjang, proses pembelajaran akan memberikan pandangan bahwa guru atau instruktur bukanlah satu-satunya sumber belajar. Media dapat mewakili apa yang kurang mampu pendidik ucapkan melalui kata-kata atau kalimat tertentu. Keabstrakan materi dapat dikonkritkan dengan kehadiran media pada proses pendidikan.

Pembelajaran dengan menggunakan media pembelajaran diarahkan pada peningkatan aktivitas dalam proses pembelajaran berlangsung secara optimal berimbas kepada pemahaman isi materi oleh peserta didik pada gilirannya dapat meningkatkan minat belajar peserta didik. Dengan kata lain, untuk meningkatkan minat belajar diperlukan peran guru yang kreatif yang dapat mengemas pembelajaran biologi menjadi lebih baik, menarik dan disukai oleh peserta didik. Oleh karena itu, ide-ide kreatif guru sangat diperlukan untuk meminimalisir kendala yang terkait dengan penguasaan media pembelajaran.

Pendidikan di sekolah dilakukan dalam proses pembelajaran. Proses pembelajaran merupakan aspek yang sangat penting dalam menentukan keberhasilan peserta didik. Pada jenjang pendidikan SMA/MA terdapat pemberian pembelajaran biologi. Pembelajaran biologi merupakan proses belajar yang menyangkut hubungan antara makhluk hidup dengan lingkungannya. Tujuan pembelajaran biologi adalah agar peserta didik dapat memahami, 
menemukan dan menjelaskan konsep-konsep, prinsip-prinsip dalam biologi (Rosmaini, Suryawati, Mariani, 2010:3). Artinya bahwa pembelajaran biologi menekankan pada pemberian pengalaman secara langsung sehingga peserta didik perlu dibantu untuk mengembangkan sejumlah keterampilan proses agar mereka mampu mengenali dan memahami organ tubuhnya sendiri.

Pada era globalisasi saat ini perkembangan teknologi informasi semakin pesat. Hal ini akan berdampak pada suatu cara baru dalam kehidupan seperti berbagai kebutuhan secara elektronik sehingga segala sesuatunya dituntut untuk serba praktis, cepat dan tepat. Sebagai masyarakat tidak dapat mengelak dari pengaruh era global tersebut, sehingga harus memiliki sasaran yang hendak dicapai dari upaya pengembangan teknologi informasi.

Adanya perkembangan teknologi dan informasi dalam dunia pendidikan seharusnya memberikan kemudahan terhadap proses pembelajaran terjadi adanya penyampaian informasi, dimana dalam penyampaiannya dapat menggunakan alat- alat sebagai penyampai informasi inilah yang disebut dengan media pembelajaran. Kedudukan media dalam proses pembelajaran mempunyai arti yang sangat penting. Bahan atau materi yang akan disampaikan dalam kegiatan pembelajaran dapat dibantu dengan menghadirkan media sebagai perantara. Namun kenyataan di lapangan kemajuan teknologi belum banyak dimanfaatkan dalam proses pembelajaran, terutama dalam hal menggunakan media pembelajaran. Penggunaan media pembelajaran saat ini lebih banyak berupa text-book yang kurang menarik minat baca peserta didik.

Komik didefinisikan sebagai bentuk kartun yang mengungkapkan karakter dan menerapkan suatu cerita dalam urutan yang erat hubungannya dengan gambar dan dirancang untuk memberikan hiburan kepada pembacanya (Daryanto, 2010:127). Selain itu, komik mempunyai kekuatan untuk menyampaikan informasi yang mudah dimengerti. Hal ini dimungkinkan karena komik memadukan kekuatan gambar dan tulisan yang dirangkai dalam suatu alur cerita yang membuat informasi mudah diserap karnateksnya mudah dimengerti dan alur cerita membuatnya mudah dipahami dan diingat.

Komik pembelajaran menyajikan unsur visual dan cerita yang kuat. Gambar yang divisualisasikan membuat pembaca tertarik untuk terus 
membacanya hingga selesai. Hal ini menginspirasi komik yang berisi materimateri pelajaran. Kecenderungan yang ada peserta didik tidak begitu menyukai buku-buku teks atau buku yang disertai gambar dengan ilustrasi yang tidak menarik. Padahal peserta didik cenderung lebih menyukai buku yang bergambar yang penuh warna dan divisiualisasikan dalam bentuk realitis ataupun kartun. Komik pembelajaran diharapkan mampu meningkatkan hasil belajar peserta didik.

Komik tidak hanya sebagai media hiburan saja, tetapi juga media edukatif yang sangat baik untuk diberikan kepada peserta didik. Komik pembelajaran sebagai media berperan sebagai alat yang berfungsi untuk menyampaikan pesan pembelajaran yang menunjukan pada sebuah proses komunikasi antara pembelajaran dan sumber belajar. Komunikasi belajar akan berjalan dengan maksimal jika pesan pembelajaran disampaikan secara jelas, runtut, dan menarik. Komikpun mengalami perubahan seiring dengan perkembangan ilmu pengetahuan dan teknologi, sekarang komik tidak hanya berbentuk cetakan tetapi juga dapat berbentuk digital atau sering disebut dengan komik digital. Menurut Uji Siti Barokah bahwa :

Komik digital adalah komik yang berbentuk format digital berbasis elektronik yang tidak hanya menampilkan alur cerita saja, namun di dalamnya dapat disisipkan game, animasi, film, atau aplikasi lainnya yang mempermudah pembaca dalam mengikuti dan menikmati tiap cerita dan penyampaiannya dapat dilakukan secara on-line ataupun melalui gadget tertentu (Barokah, 2014:6).

Dengan adanya komik digital ini diharapkan dapat meningkatkan minat peserta didik sehingga pada akhirnya dapat meningkatkan pemahaman materi peserta didik. Berdasarkan hasil wawancara oleh guru biologi di MAN 2 Bandar Lampung pada proses pembelajaran biologi materi sistem hormon pada satu tahun sebelumnya peserta didik belum dapat menguasai materi itu. Secara garis besarnya, peserta didik belum dapat menguasai isi materi belajar biologi pada materi sistem hormon (Suhanda, 2017).

Materi sistem endokrin dipilih sebagai wadah penelitian karena materi ini mengkaji tentang pengenalan tentang fungsi beberapa organ dalam aktivitas manusia dalam kehidupan sehari-hari. Alasan peneliti memilih materi ini karena materi sistem hormon merupakann materi yang cukup rumit dalam pemahaman 
materinya. Sehingga diperlukan media yang mempermudah peserta didik dalam pemahaman materi sistem hormon.

Berdasarkan hasil wawancara selanjutnya oleh guru Biologi di MAN 2 Bandar Lampung proses pembelajaran biologi, bahwa beberapa tahun sebelumnya terdapat penelitian berupa komik pada pembelajaran biologi di MAN 2 Bandar Lampung. Komik tersebut terbuat dari kertas yang dicetak menjadi buku komik bergambar. Akan tetapi dengan termakan usia waktu sehingga sekarang terlihat kusam dan terdapat beberapa lipatan-lipatan dan sobekan pada lembar halaman komik tersebut, serta warna pada gambar komik yang mulai memudar.

Kelemahan itulah yang menjadi sebuah acuan bagi peneliti untuk mengembangkan komik itu menjadi sebuah komik yang tidak mudah rusak baik pada kertas ataupun warnanya. Di era globalisasi ini terdapat teknologi canggih seperti gadget-gadget dengan berbagai merek. Sementara itu sebagian besar gadget-gedget canggih itu dimiliki oleh peserta didik, salah satu contoh dari gadget itu adalah android yang sudah banyak dimiliki peserta didik, tetapi belum dimanfaatkan dalam penggunaan media pembelajaran. Dengan menggunakan android tersebut akan menyediakan media pembelajaran komik manga digital sebagai alternatif dalam pengembangan dan perbaikan media pembelajaran disekolah.

Berdasarkan angket yang diberikan serta observasi proses pembelajaran pada kelas XI IPA di MAN 2 Bandar Lampung, bahwa pada proses pembelajaran dikelas sebagian peserta didik tidak membawa buku paket, karena kurang praktis, dan tidak bisa dibawa kemana saja dan mudah dipelajari dimana saja. Selain itu peserta didik lebih tertarik pada media pembelajaran yang memiliki gambar yang menarik, serta peserta didik mempunyai android yang terhubung ke akses internet dan belum dimanfaatkan sepenuhnya dalam proses belajar, akan tetapi lebih dimanfaatkan untuk sosial media, game, menonton video saja.

Berdasarkan permasalahan tersebut, maka perlu dicari pemecahan masalahnya. Salah satu yang diduga untuk memecahkan masalah tersebut yaitu media pembelajaran yang sesuai dan penelitian yang relevan. Karena itu pembelajaran biologi tidak terlepas dari media dan bahan ajar yang umum dan 
sering digunakan berupa buku teks modul dengan ciri khas banyak berisi tulisan atau penjelasan dengan kalimat dan sedikit disertai gambar yang cenderung membuat peserta didik bosan dan kurang termotivasi. Pada beberapa kasus peserta didik cenderung tidak menyukai buku teks apalagi yang tidak disertai gambar dan ilustrasi yang menarik. Secara emperis peserta didik cenderung menyukai buku bergambar, penuh dengan warna, dan divisualisasikan dalam bentuk realitis atau kartun yang lebih tepatnya disebut media komik.

Komik yang menjadi bahan pengembangan peneliti memiliki kelebihan dari media pembelajaran komik lainnya, komik manga digital diantaranya merupakan media komunikasi visual yang memiliki kekuatan untuk menyampaikan pesan atau informasi secara ringkas dan mudah dimengerti, terdiri dari gambar yang tidak bergerak dan tulisan yang dirangkai dalam suatu alur cerita dengan menggunakan bahasa verbal dan logis dan mudah dibawa kemana saja dan tidak rusak dimakan usia, karna dibuat dalam bentuk digital bukan dengan menggunakan kertas, disertakan gaya penggambaran karakter komik bergaya khas Jepang yang sedang disukai para remaja sekarang ini. Sedangkan kelemahannya adalah hanya bisa diakses secara on-line. Media komik manga digital ini digunakan untuk mempermudah pemahaman materi peserta didik akan materi pembelajarannya. Hal ini dikarenakan pada materi sistem hormon ini masih kurangnya pemahaman pada peserta didik. Dengan demikian, penggunaan media komik manga digital cocok untuk diterapkan pada peserta didik disekolah.

Berdasarkan uraian tersebut, maka penulis mencoba memberikan alternatif dengan menggunakan suatu komik pembelajaran biologi yang mudah diakses di era modern sebagai sumber belajar agar peserta didik mudah memahaminya, yaitu dengan menggunakan komik manga digital dalam pembelajaran biologi pada materi sistem endokrin. Penggunaan komik digital pembelajaran biologi ini, peserta didik akan lebih banyak beraktivitas dan pembelajaran akan menjadi aktif, inovatif, kreatif, efektif, dan menyenangkan, serta mudah menguasai isi materi.

Penelitian ini memiliki rumusan masalah antara lain; Bagaimana mengembangkan media pembelajaran komik manga digital berbasis android 
pada materi sistem hormon untuk kelas XI di MAN 2 Bandar Lampung yang memudahkan pemahaman materi belajar biologi oleh peserta didik? dan Bagaimanakah kelayakkan pengembangan media komik manga digital berbasis android pada materi sistem hormon untuk peserta didik kelas XI berdasarkan penilaian ahli materi, ahli media, ahli bahasa, guru biologi dan peserta didik?

Sedangkan tujuan umum dari penelitian ini antara lain; Untuk mengetahui cara mengembangkan media pembelajaran komik manga digital berbasis android pada materi sistem hormon untuk kelas XI di MAN 2 Bandar Lampung yang memudahkan pemahaman materi belajar biologi oleh peserta didik, dan untuk mengetahui kelayakan pengembangan media komik manga digital berbasis android pada materi sistem hormon untuk peserta didik kelas XI berdasarkan penilaian ahli materi, ahli media, ahli bahasa, guru biologi dan peserta didik.

Spesifikasi produk dalam penelitian ini antara lain; Komik manga digital berbasis android pada materi sistem hormon untuk SMA/MA kelas XI semester genap, Komik manga digital berbasis android disimpan dalam bentuk aplikasi android, Komik manga digital berbasis android dibuat menggunakan Photoshop dan Comipo, Komik manga digital berbasis android memuat gambar yang mewaliki beberapa isi pada materi sistem hormon sehingga mudah dipahami, Komik manga digital berbasis android dilengkapi dengan Standar Kompetensi, Kompetensi Dasar, Indikator yang harus dicapai, pengenalan tokoh atau karakter, narasi tentang materi, dan evaluasi, Komik manga digital berbasis android dapat digunakan untuk pembelajaran biologi dalam kelas ataupun secara mandiri oleh peserta didik.

\section{METODE PENELITIAN}

Metode yang digunakan pada penelitian ini adalah metode penelitian dan pengembangan (Reseach and Development). Prosedur yang digunakan adalah menurut Borg \& Gall yang menyatakan bahwa pendekatan Research and Development (R\&D) dalam pendidikan meliputi sepuluh langkah tahapan (Gall, Borg, 2003, 772).

Tetapi menurut Borg and Gall dalam Wina Sanjaya tahapan yang ideal tersebut dapat disederhanakan tanpa mengurangi nilai penelitian dan 
pengembangan itu sendiri (Sanjaya, 2013:135). Oleh karena itu, penelitian ini disederhanakan menjadi tujuh tahapan. Dikarenakan tujuan penelitian ini adalah untuk mengetahui kelayakan media yang dikembangkan dan dengan memperkirakan waktu, dan dana yang dimiliki. 7 tahapan tersebut adalah; 1.Research and development collecting, 2.Planning, 3.Develop preliminary of product, 4.preliminary field testing, 5.Main product revesion, 6.Main field test, 7. Operational product revision.

Populasi dalam penelitian ini adalah seluruh peserta didik kelas XI MIA di MAN 2 Bandar Lampung yang berjumlah 197 peserta didik yang terdiri kelas XI MIA 1 sampai MIA 5. Pada penelitian ini juga terdapat dua sampel yang diuji yaitu sampel uji skala luas semua peserta didik kelas XI MIA 1 yang berjumlah 40 peserta didik, sedangkan sampel uji skala terbatas terbatas yang digunakan adalah 10 peserta didik kelas XI MIA 1 yang diambil hanya 25\% saja dari jumlah 40 peserta didik yang ada sesuai dengan apa yang dikatakan Suharsimi Arikunto, bahwa jika jumlah subjeknya besar, dapat diambil antara 20-25\% (Arikunto, 2006:134).

Teknik Pengumpulan data terdiri dari wawancara, observasi, angket, dan dokumentasi. Kemudian Instrumen penelitiannya adalah wawancara, observasi, angket kebutuhan, angket validasi ahli, angket tanggapan guru, angket tanggapan peserta didik, dan dokumentasi. Selanjutnya teknik analisis data yaitu angket kebutuhan dan angket validasi. Untuk mempermudah dalam membaca data maka digunakannya skor skala linkert sebagai berikut:

Tabel 1. Skor Skala Linkert

\begin{tabular}{ccccc}
\hline Pertanyaan & $\begin{array}{c}\text { Sangat } \\
\text { setuju }\end{array}$ & Setuju & Tidak setuju & $\begin{array}{c}\text { Sangat tidak } \\
\text { setuju }\end{array}$ \\
\hline Positif (+) & 4 & 3 & 2 & 1 \\
\hline Negatif (-) & 1 & 2 & 3 & 4 \\
\hline \multicolumn{2}{r}{ Sumber : Riduwan, Dasar-dasar Statistika, (Bandung : Alfabeta, 2009), h.39. }
\end{tabular}

Berdasarkan data hasil data tersebut dapat dianalisis dengan menghitung persentase jawaban tersebut menggunakan rumus berikut (Sudijono, 2001:35)

$$
N P=\frac{R}{N S} \times 100 \%
$$

Keterangan:

NP

: Nilai persen yang dicari atau diharapkan 
R : Jumlah skor yang diperoleh siswa

NS : Total skor maksimal.

Berdasarkan persentase hasil skor skala linkert yang didapatkan tersebut kemudian di interprestasikan dalam kategori kelayakan berdasarkan tabel berikut:

Tabel 2. Kriteria Kelayakan

\begin{tabular}{cc}
\hline Skor rata-rata $(\%)$ & Kategori \\
\hline $25 \% \leq \mathrm{V} \leq 43,74 \%$ & Tidak lavak \\
\hline $43,75 \% \leq \mathrm{V} \leq 62,4 \%$ & Kurang lavak \\
\hline $62,5 \% \leq \mathrm{V} \leq 81,24 \%$ & Lavak \\
\hline $81.25 \%<\mathrm{V}<100 \%$ & Sangat lavak \\
\hline
\end{tabular}

Sumber : Riduwan, Dasar-dasar Statistika, (Bandung : Alfabeta, 2009), h.40-41.

\section{HASIL DAN PEMBAHASAN}

Penelitian dan pengembangan ini dilaksanakan untuk menghasilkan sebuah media pembelajaran komik manga digital. Tahapan prosedur yang digunakan adalah 7 tahapan dari 10 Borg and Gall, yang disederhanakan tanpa mengurangi nilai penelitian dan pengembangan itu sendiri. Ketujuh tahapan itu diantaranya sebagai berikut :

\section{Research and Information Collecting}

Pada tahapan ini masalah yang ditemukan adalah peserta didik belum menguasai materi sistem hormon, media ajar seperti buku paket yang kurang praktis karna tidak bisa fleksibel dibawa kemana saja, dan peserta didik yang lebih tertarik pada pembelajaran yang menggunakan gambar yang menarik, dan teknologi yang belum dimanfaatkan sepenuhnya.

\section{Planning}

Pada tahap perencanaan ini penelitian dilaksanakan dengan mulai mengumpulkan seluruh data dan perlengkapan yang dibutuhkan pada proses penelitian yang meliputi merumuskan tujuan penelitian serta merumuskan tahapan penelitian, memperhitungkan dana, tenaga, dan waktu, serta hal lain yang berkaitan dalam penelitian.

\section{Develop Preliminary of Product}

a. Pengembangan desain

Pada tahap ini, peneliti menentukan desain awal dan sarana yang digunakan pada proses pembuatannya yaitu dengan program software Comipo! untuk 
mengatur semua desain untuk komik, dan Photoshop CS 5 untuk mengatur gambar sesuai ukuran yang dibutuhkan serta software on-line App Bulid Appy Pie untuk merubah format produk menjadi android.

b. Validasi oleh ahli materi, ahli bahasa, ahli media, dan guru.

Setelah desain produk selesai, kemudian dilakukan penilaian oleh ahli materi, ahli bahsa, dan ahli media. Dari hasil masing-masing penilaian yang diberikan oleh para ahli, media yang dikembangkan dinyatakan valid dan layak digunakan sebagai pembelajaran setelah dilakukannya revisi. Hasil tersebut dapat dilihat pada tabel berikut ini:

Tabel 3. Hasil Tabulasi Uji Ahli Materi

\begin{tabular}{ccc}
\hline Hasil Pesentase & Kriteria & Keterangan \\
\hline $83,75 \%$ & Sangat Layak & Revisi \\
\hline \multicolumn{3}{c}{ Sumber : Dokumentasi pribadi penelitan } \\
& \\
Tabel 4. Hasil Tabulasi Uji Ahli Bahasa \\
\hline Hasil Pesentase & Kriteria & Keterangan \\
\hline $93,75 \%$ & Sangat Layak & Tanpa Revisi \\
\hline \multicolumn{2}{c}{ Sumber : } \\
\hline
\end{tabular}

Tabel 5. Hasil Tabulasi Uji Ahli Media

\begin{tabular}{ccc}
\hline Hasil Pesentase & Kriteria & Keterangan \\
\hline $85,8 \%$ & Sangat Layak & Revisi \\
\hline \multicolumn{2}{c}{ Sumber : Dokumentasi pribadi penelitan }
\end{tabular}

Tabel 6. Hasil Tabulasi Tanggapan Guru

\begin{tabular}{ccc}
\hline Hasil Pesentase & Kriteria & Keterangan \\
\hline $86,25 \%$ & Sangat Layak & Tanpa Revisi \\
\hline \multicolumn{2}{c}{ Sumber : Dokumentasi pribadi penelitan }
\end{tabular}

c. Revisi desain

Kelayakan produk ini tidak terlepas dari masukan dan saran oleh para ahli. Perbaikan yang dilakukan terhadap produk yang dikembangkan berpedoman dari masukan, tanggapan, dan saran yang diperoleh dari para ahli dan guru.

\section{Preliminary field testing}

Uji coba terbatas ini dilakukan setalah produk divalidasi dan direvisi. Uji coba dilakukan kepada sekelompok kecil peserta didik kelas XI MIA yang 
berjumlah 10 orang peserta didik. Hasil tersebut dapat dilihat pada tabel berikut ini:

Tabel 7. Hasil Uji Coba Terbatas Terhadap Komik Manga Digital

\begin{tabular}{cccccc}
\hline No. & Responden & Jumlah Nilai & Nilai Maksimal & Persentase & Kriteria \\
\hline 1. & RL1 & 48 & 52 & $92,3 \%$ & Sangat Layak \\
\hline 2. & RP1 & 47 & 52 & $90,4 \%$ & Sangat Layak \\
\hline 3. & RL2 & 46 & 52 & $88,5 \%$ & Sangat Layak \\
\hline 4. & RP2 & 45 & 52 & $86,5 \%$ & Sangat Layak \\
\hline 5. & RL3 & 45 & 52 & $86,5 \%$ & Sangat Layak \\
\hline 6. & RP3 & 44 & 52 & $84,6 \%$ & Sangat Layak \\
\hline 7. & RL4 & 44 & 52 & $84,6 \%$ & Sangat Layak \\
\hline 8. & RP4 & 45 & 52 & $86,5 \%$ & Sangat Layak \\
\hline 9. & RL5 & 46 & 52 & $88,5 \%$ & Sangat Layak \\
\hline 10. & RP5 & 45 & 52 & $86,5 \%$ & Sangat Layak \\
\hline & Jumlah & 455 & 520 & $87,5 \%$ & Sangat Layak \\
\hline
\end{tabular}

\section{Main Product Revesion}

Pada uji coba lapangan terbatas tidak terlau banyaknya saran dan tanggapan dari peserta didik. Beberapa dari peserta didik menilai bahwa background dengan warna hijau terlalu cerah. Kemudian desain grafiknya lebih ditingkatkan lagi.

\section{Main Field Test}

Uji coba terbatas ini dilakukan setalah uji produk skala terbatas. Uji coba dilakukan kepada peserta didik kelas XI MIA yang berjumlah 40 orang peserta didik. Hasil tersebut dapat dilihat pada tabel berikut ini:

Tabel 8. Hasil Uji Coba Luas Terhadap Komik Manga Digital

\begin{tabular}{cccccc}
\hline No. & Responden & Jumlah Nilai & Nilai Maksimal & Persentase & Kriteria \\
\hline 1. & RL1 & 29 & 52 & $55,8 \%$ & Kurang Layak \\
\hline 2. & RP1 & 52 & 52 & $100 \%$ & Sangat Layak \\
\hline 3. & RL2 & 47 & 52 & $90,4 \%$ & Sangat Layak \\
\hline 4. & RP2 & 39 & 52 & $75 \%$ & Layak \\
\hline 5. & RL3 & 52 & 52 & $100 \%$ & Sangat Layak \\
\hline 6. & RP3 & 38 & 52 & $73,1 \%$ & Layak \\
\hline 7. & RL4 & 52 & 52 & $100 \%$ & Sangat Layak \\
\hline 8. & RP4 & 36 & 52 & $69,2 \%$ & Layak \\
\hline 9. & RL5 & 39 & 52 & $75 \%$ & Layak \\
\hline 10. & RP5 & 39 & 52 & $75 \%$ & Layak \\
\hline 11. & RP6 & 45 & 52 & $86,5 \%$ & Sangat Layak \\
\hline
\end{tabular}




\begin{tabular}{|c|c|c|c|c|c|}
\hline 12. & RL6 & 52 & 52 & $100 \%$ & Sangat Layak \\
\hline 13. & RP7 & 41 & 52 & $78,8 \%$ & Layak \\
\hline 14. & RP8 & 52 & 52 & $100 \%$ & Sangat Layak \\
\hline 15. & RP9 & 37 & 52 & $71,2 \%$ & Layak \\
\hline 16. & RP10 & 39 & 52 & $75 \%$ & Layak \\
\hline 17. & RP11 & 52 & 52 & $100 \%$ & Sangat Layak \\
\hline 18. & RP12 & 39 & 52 & $75 \%$ & Layak \\
\hline 19. & RP13 & 42 & 52 & $80,8 \%$ & Layak \\
\hline 20. & RL7 & 48 & 52 & $92,3 \%$ & Sangat Layak \\
\hline 21. & RL8 & 38 & 52 & $73,1 \%$ & Layak \\
\hline 22. & RP14 & 44 & 52 & $84,6 \%$ & Sangat Layak \\
\hline 23. & RL9 & 39 & 52 & $75 \%$ & Layak \\
\hline 24. & RL10 & 46 & 52 & $88,5 \%$ & Sangat Layak \\
\hline 25. & RP15 & 39 & 52 & $75 \%$ & Layak \\
\hline 26. & RP16 & 42 & 52 & $80,8 \%$ & Layak \\
\hline 27. & RP17 & 40 & 52 & $76,9 \%$ & Layak \\
\hline 28. & RL11 & 45 & 52 & $86,5 \%$ & Sangat Layak \\
\hline 29. & RL12 & 52 & 52 & $100 \%$ & Sangat Layak \\
\hline 30. & RP18 & 39 & 52 & $75 \%$ & Layak \\
\hline 31. & RP19 & 39 & 52 & $75 \%$ & Layak \\
\hline 32. & RP20 & 39 & 52 & $75 \%$ & Layak \\
\hline 33. & RP21 & 45 & 52 & $86,5 \%$ & Sangat Layak \\
\hline 34. & RP22 & 44 & 52 & $84,6 \%$ & Sangat Layak \\
\hline 35. & RL13 & 44 & 52 & $84,6 \%$ & Sangat Layak \\
\hline 36. & RP23 & 39 & 52 & $75 \%$ & Layak \\
\hline 37. & RL14 & 46 & 52 & $88,5 \%$ & Sangat Layak \\
\hline 38. & RP24 & 45 & 52 & $86,5 \%$ & Sangat Layak \\
\hline 39. & $\mathrm{RP} 25$ & 40 & 52 & $76,9 \%$ & Layak \\
\hline \multirow[t]{2}{*}{40.} & RP26 & 39 & 52 & $75 \%$ & Layak \\
\hline & Jumlah & 1714 & 2080 & $82,4 \%$ & Sangat Layak \\
\hline
\end{tabular}

\section{Operational Product Revesion}

Pada hasil uji coba lebih luas ditemukannya saran dan tanggapan dari peserta didik yaitu ada beberapa smartphone mereka yang tidak mendukung aplikasi ini, dikarenakan smartphone yang digunakan adalah bukan tipe Android melainkan iOS (iPhone Operation System). Saran dan tanggapan peserta didik ini dapat dijadikan bahan revisi untuk memperbaiki pengembangan produk agar dapat digunakan dalam smartphone tipe iOS (iPhone Operation System).

\section{SIMPULAN}

Berdasarkan hasil peneliti yang lakukan pada penelitian dan pengembangan, maka diperoleh kesimpulan bahwa : 
1. Pengembangan media komik manga digital untuk mempermudah pembelajaran biologi pada peserta didik kelas XI di MAN 2 Bandar Lampung telah berhasil dibuat dengan menggunakan berbagai software yang membantu pembuatan produk, seperti software Comipo! yang digunakan untuk pembuatan komik manga, selanjutnya dibantu dengan sofware online App Build Appy Pie yang membuat komik manga kertas menjadi sebuah komik manga yang digitalis karena terdapat dalam bentuk aplikasi android.

2. Media pembelajaran komik manga digital yang sudah dikembangkan memiliki nilai kelayakan yang sangat layak, hal ini dilihat berdasarkan penilaian ahli materi dengan persentase kelayakan mencapai 83,75\%, kemudian penilaian ahli bahasa dengan persentase kelayakan mencapai 93,75\%, selanjutnya penilaian ahli media dengan persentase kelayakan mencapai $85,8 \%$, dan penilaian tanggapan guru dengan persentase kelayakan mencapai $86,25 \%$, serta tanggapan peserta didik dengan persentase kelayakan mencapai $82,4 \%$.

Berdasarkan hasil penelitian dan kesimpulan dapat dikemukakan beberapa saran sebagai berikut :

1. Bagi Guru

Untuk dapat memberikan kegitan pembelajaran dengan menggunakan media pembelajaran komik manga digital pada peserta didik dengan tingkat kekampuan berpikir yang beragam.

2. Bagi Peserta Didik

a. Untuk dapat memudahkan pemahaman pembelajaran peserta didik dalam pelajaran pada bidang biologi.

b. Untuk dapat lebih pandai dalam memanfaatkan alat teknologi yang tersedia.

3. Bagi Sekolah

Untuk dapat menggunakan secara optimal sarana dan prasarana serta teknologi yang tersedia. Juga dalam mengaplikasikan komik manga digital sebagai media pembelajaran disekolah.

4. Bagi Peneliti lain 
a. Perlu lebih dikembangkan kembali komik manga digital dengan materi yang lainnya.

b. Untuk dapat melanjutkan media pembelajan komik manga digital ini hingga tahapan kesepuluh menurut Borg and Gall, yaitu tahapan Dissemination and Implementation untuk menguji cobakan keefektifan media pembelajaran serta mengetahui pengaruhnya terhadap peningkatan kualitas pembelajaran biologi dalam materi Sistem Hormon.

c. Untuk dapat dibuat dalam format aplikasi smartphone Apple yang memiliki bentuk sistem iOS (iPhone Operation System).

\section{DAFTAR PUSTAKA}

Arikunto, S. (2006). Prosedur Penelitian Suatu Pendekatan Praktek. Yogyakart: Rineka Cipta.

Barokah, U.S. (2014). Pengembangan Komik Digital Berbasis Nilai Karakter Sebagai Media Pembelajaran Akuntansi Pada Kompetensi Dasar Menyusun Laporan Keuangan Perusahan Jasa untuk SMA Kelas XI. Skripsi Pendidikan. Fakultas Ekonomi UNY.

Borg and Gall. (2003). Educational Research, An Introduction. New York and London : Longman Inc.

Daryanto. (2010). Media Pembelajaran Peranannya Sangat Penting Dalam Mencapai Tujuan Pembelajaran. Yogyakarta : Gava Media.

Riduwan. (2009). Dasar-dasar Statistika. Bandung : Alfabeta.

Rosmaini, S, E, \& Mariani N. L, (2010). "Penerapan Pendekatan Struktual ThinkPair-Share (TPS) Untuk Meningkatkan Hasil Belajar”. Jurnal Pendidikan, 2010.

Sanjaya, W. (2013). Penelitian Pendidikan : Jenis, Metode, dan Prosedur. Jakarta : Prenada Media Group.

Sudarma, K., dkk. (2014). Pengaruh model Kooperatif Two Stay Two stray Terhadap Hasil Belajar IPA. Jurnal Mimbar PGSD Universitas Pendidikan Ganesha. Vol. 2 No.1.

Sudijono, A. (2001). Pengantar Evaluasi Pendidikan. Jakarta: Rajawali Press

Suhanda. (2017). Hasil Wawancara dengan Guru Biologi Ibu Eny Supriyanti. Bandar Lampung. 